\title{
Exploring Bikaverin as Metal Ion Biosensor: A Computational Approach
}

\author{
Zakir Hussain, ${ }^{1}$ Haamid Rasool Bhat, ${ }^{2}$ Tahira Naqvi, ${ }^{3}$ Malay K. Rana ${ }^{2}$ \\ and Masood Ahmad Rizvi ${ }^{1, *}$ \\ ${ }^{1}$ Department of Chemistry, University of Kashmir, Hazratbal, Srinagar J\&K, India. \\ ${ }^{2}$ Department of Chemical Sciences, IISER, Berhampur, Odisha, India. \\ ${ }^{3}$ Department of Chemistry, Degree College for Women M.A. Road Srinagar J\&K, India \\ *Corresponding author: E-mail: masoodku2@gmail.com
}

Received: 11-12-2018

\begin{abstract}
A computational exploration of fungi produced pigment bikaverin as a biosensor towards bioavailable metal ions is presented. Systematic studies of the optimized ground and excited state geometries were attempted for exploring metal ion binding pocket, comparative binding propensity and optical properties of the bikaverin and its adducts with studied metal ions. The screening of thirteen (13) bioavailable metal ions, revealed a range of binding strength towards bikaverin receptor with $\mathrm{Ca}^{2+}, \mathrm{Mg}^{2+}$ and $\mathrm{Al}^{3+}$ as the strongest binders. Besides, upon binding to bikaverin receptor an enhancement in its fluorescence intensity was observed in the order $\mathrm{Ca}^{2+}>\mathrm{Al}^{3+}>\mathrm{Mg}^{2+}$. The computationally predicted selectivity of bikaverin receptor towards $\mathrm{Ca}^{2+}$ was experimentally corroborated through the preliminary fluorescence studies. The bikaverin probe showed an enhancement of fluorescence emission in presence of $\mathrm{Ca}^{2+}$ ions in buffered aqueous medium.
\end{abstract}

Keywords: Computational chemistry; Biosensors; Fluorescence Spectroscopy; Quantum chemical calculations; Electronic structure

\section{Introduction}

The well designed computational studies can be good to predict the starting point for targeted experiments in a time and cost effective manner. ${ }^{1}$ Experimental chemists use theoretical calculations to supplement, support and guide their experiments particularly in the areas of conformational analysis, ${ }^{2}$ reaction mechanism, ${ }^{3}$ transition states, ${ }^{4}$ charge distributions, ${ }^{5}$ modeling larger molecules like DNA and proteins, ${ }^{6}$ structure-activity relationships, ${ }^{7}$ orbital interactions, ${ }^{8}$ and excited state studies. ${ }^{9}$ Metal ions are required for a plethora of functions in biosystems. However, the metal ions can be like double-edged swords; at their proper concentrations, these remain coordinated to their natural binding sites and perform the desired functions; but a change in their normal concentration can lead to their de-compartmentalization and consequently bring onset of deleterious functions. ${ }^{10}$ Therefore, selective sensors for detection and quantification of metal ions for the real time analytical monitoring and medical diagnosis are of considerable importance. ${ }^{11}$
Thus, it becomes imperative to investigate the natural bioactive compounds for their in vivo metal ion sensing applications in order to potentiate the diagnosis for better therapeutic action. In continuation of our computational chemistry interests ${ }^{12-15}$ and towards investigating the bioactivities of natural products, ${ }^{16-18}$ we attempted to survey the fungi derived fluorescent bioactive natural product bikaverin for metal ion sensing ability. Bikaverin is a reddish pigment produced by different fungal species of the genus Fusarium with the diverse biological activities. ${ }^{19-21}$ With the increasing reports on its pharmacological role, bikaverin is becoming a metabolite of biotechnological interest. ${ }^{22}$ Commercially bikaverin as pure compound is costly and synthesizing bikaverin through a total chemical process is less viable and environmentally unfavorable. However, obtaining bikaverin from microbial sources present an environment friendly, continuousand cheap source. Thus for obtaining bikaverin in a cost effective and an environment friendly manner, we extracted bikaverin from fungal extracts using the standardized procedure from literature reports. ${ }^{23}$ In this study, we present the 
computational exploration of bikaverin as biosensor towards thirteen (13) bioavailable metal ions. The computational prediction was experimentally confirmed through preliminary florescence studies of studied metal ions as bikaverin adducts.

\section{Experimental}

\section{1. Computational Procedures and Materials}

All density functional theory (DFT) and time-dependent density functional theory (TD-DFT) calculations were performed using the Gaussian 09 program package. ${ }^{24}$ The geometries of all the studied molecules (bikaverin and its metals adducts) were fully optimized at the singlet ground (S0) and first excited (S1) states in the acetonitrile solvent using CAM-B3LYP, Coulomb-attenuating method based on Becke's three parameter hybrid exchange and nonlocal correlation functional of Lee, Yang and Parr (65\% exchange and $35 \%$ correlation weighting at longrange). ${ }^{25,26}$ The standard 6-311G, split-valence atomic basis set function of DFT has been employed for all the atoms except for the transition metal ions; Nickel $\left(\mathrm{Ni}^{2+}\right)$, Mercury $\left(\mathrm{Hg}^{2+}\right)$, Cadmium $\left(\mathrm{Cd}^{2+}\right)$, Manganese $\left(\mathrm{Mn}^{2+}\right)$, Iron $\left(\mathrm{Fe}^{2+}\right)$, Zinc $\left(\mathrm{Zn}^{2+}\right)$, Copper $\left(\mathrm{Cu}^{2+}\right)$ and Lead $\left(\mathrm{Pb}^{2+}\right)$ atoms for which effective core potential (ECP) of Wadt and Hay pseudo-potential with a double- $\zeta$ valence basis set LANL2DZ was used. ${ }^{27-29}$ It is because the LANL2DZ reduces the computational cost as it uses an effective core potential for the core electrons, thus the core electrons are not explicitly considered in the computation. For the structural calculations of receptor-transition metal complexes, the relativistic LANL2DZ pseudopotential is the typical basis set asit has been identified to give close agreement between calculated and experimentally observed geometries. Frequency calculations were carried out to verify that the optimized molecular structures correspond to the energy minima, thus only positive frequencies were expected. The TD-DFT studies of all the molecules were performed by utilizing the same functional and the basis sets as CAM-B3LYP has been shown to be good for the excited state property calculations. ${ }^{30}$ The Conductor-like Polarizable Continuum Model (CPCM) was utilized for taking care of the effect of solvation in acetonitrile (dielectric constant, $\varepsilon=37.5$ ) on all the calculations as implemented in Gaussian 09. Natural Bond Orbital (NBO) method was employed for the natural population analysis, using the NBO 3.1 version as implemented in Gaussian 09 program. ${ }^{31}$ Free energy changes $(\Delta G)$ and binding energies $(\Delta \mathrm{E})$ were calculated for the receptor-analyte complexes to comprehend the thermodynamic binding propensity of the selected bioavailable cations with receptor (1).The Gibb's free energy change $(\Delta G)$ of the fragments $(1), \mathrm{Na}^{+}$, $\mathrm{K}^{+}, \mathrm{Ni}^{2+}, \mathrm{Al}^{3+}, \mathrm{Hg}^{2+}, \mathrm{Cd}^{2+}, \mathrm{Mn}^{2+}, \mathrm{Fe}^{2+}, \mathrm{Zn}^{2+}, \mathrm{Cu}^{2+}, \mathrm{Mg}^{2+}$, $\mathrm{Pb}^{2+}$ and $\mathrm{Ca}^{2+}$ and their complexes were calculated from equation 1 :

$$
\Delta \mathrm{G}=\text { Gcomplex }-(\text { Greceptor }+ \text { Gcation })
$$

Where Gcomplexis the free energy of receptor-cation adduct, Greceptor and Gcation are free energies of isolated receptor and cation respectively. The binding energy changes were also calculated to check the binding selectivity of the studied cations towards bikaverin receptor using the equation 2:

$$
\Delta \mathrm{E}=(\text { Ecomplex })-(\text { Ereceptor }+ \text { Ecation })
$$

Where Ecomplex is the total energy of the receptorcation adduct, Ereceptor and Ecation are total energies of isolated receptor and cation respectively.In order to reduce basis set superposition error (BSSE) in these energy calculations, the Boys-Bernardi scheme was applied to yield the counterpoise corrected energies. ${ }^{32}$

\section{2. Extraction of Bikaverin from Fungal Extracts}

Fungal mycelium showed a growth up to $5-6 \mathrm{~cm}$ on a PDA (potato dextrose agar) plate after 7 days. The morphological features supported the genus Fusarium resulting in $99 \%$ homology with the Fusarium proliferatum. Dichloromethane solvent was used to extract the crude bikaverin using National Cancer Institute's protocol. The extract was concentrated under vacuum and subjected to purification over column chromatography on silica gel using hexane-ethyl acetate $(7: 3 \mathrm{~V}: \mathrm{V})$ mobile phase leading to the isolation of pure bikaverin.

\section{3. Absorption and Emission Studies}

All reagents were purchased from Aldrich and used without further purification. UV-Vis and fluorescence spectra were recorded on a Shimadzu UV-2450 and Shimadzu 5301 PC spectrophotometer respectively, with a quartz cuvette (path length $1 \mathrm{~cm}$ ). A $10^{-3} \mathrm{M}$ stock solution of bikaverin (probe 1) was prepared by dissolving the required amount of bikaverin in $10 \mathrm{~mL}$ of DMSO; $30 \mu \mathrm{L}$ of this stock solution was further diluted with $\mathrm{CH}_{3} \mathrm{CN}$ and HEPES buffer $(0.05 \mathrm{M}, \mathrm{pH}=7.4)$ to prepare $3 \mathrm{~mL}$ solution of probe (1) and this solution was used for each UV-Visible and fluorescence experiment. The aliquots of freshly prepared standard solutions $\left(10^{-2} \mathrm{M}\right)$ of metal chloride/ metal perchlorates $\left\{\mathrm{M}=\mathrm{Hg}^{2+}, \mathrm{Fe}^{2+}, \mathrm{Pb}^{2+}, \mathrm{Cd}^{2+}, \mathrm{Cu}^{2+}\right.$, $\mathrm{Zn}^{2+}, \mathrm{Ni}^{2+}, \mathrm{Al}^{3+}, \mathrm{Co}^{2+}, \mathrm{Mg}^{2+}, \mathrm{Ca}^{2+}, \mathrm{Na}^{+}$, and $\left.\mathrm{K}^{+}\right\}$, in distilled water were added to $3 \mathrm{~mL}$ solution of probe (1) taken in quartz cuvette and spectra's were recorded.

\section{Results and Discussions}

Quantum-chemical calculations are impressive for their step to step analysis and prediction whereas experi- 


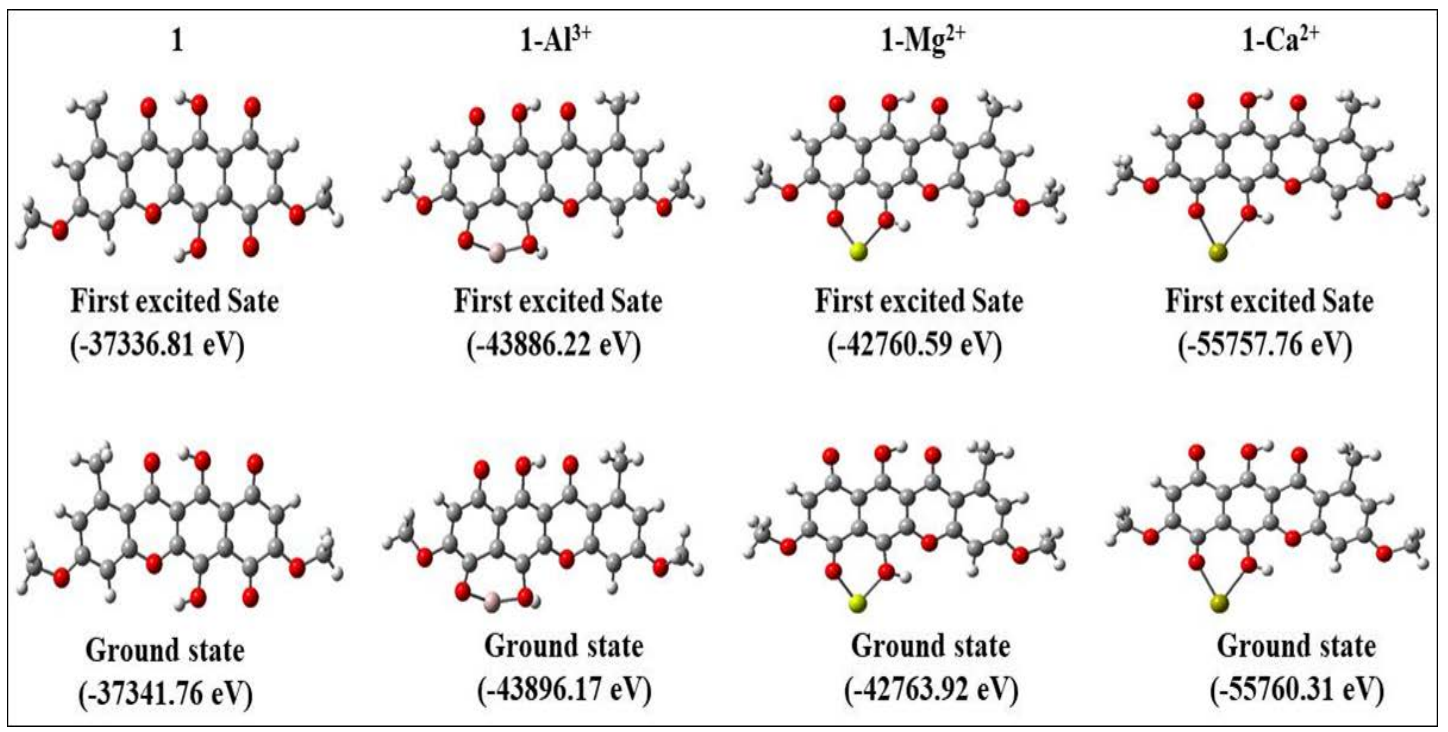

Figure 1. Optimized ground (SO) and the first excited state (S1) geometries of bikaverin receptor(1), 1- $\mathrm{Al}^{3+}, 1-\mathrm{Mg}^{2+}$ and $1-\mathrm{Ca}^{2+}$ and their corresponding energies [in electron volts $(\mathrm{eV})]$.

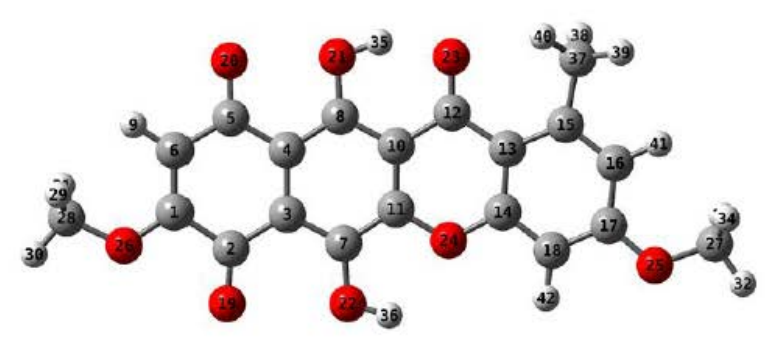

(a)

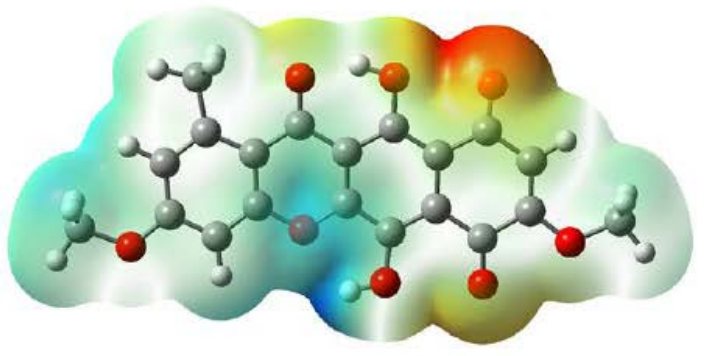

(b)

Figure 2. (a) Optimized geometry and (b) Electrostatic potential map of ground state $\left(\mathrm{S}_{0}\right)$ of bikaverin.

mental results are a net outcome of all the influencing factors in a blend.The optimized geometries and the corresponding energies of the ground and first excited state of

Table 1. The NPA Charge distribution on some crucial atoms of

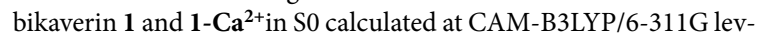
el of theory.

\begin{tabular}{ccc}
\hline Atom involved & \multicolumn{2}{c}{ NPA charge distribution } \\
& Bikaverin (1) & 1-Ca $\mathbf{C a}^{\mathbf{2 +}}$ \\
\hline O22 & -0.685 & -0.776 \\
O19 & -0.534 & -0.678 \\
O23 & -0.645 & -0.635 \\
O21 & -0.698 & -0.685 \\
O20 & -0.588 & -0.559 \\
O24 & -0.495 & -0.495 \\
O25 & -0.532 & -0.527 \\
O26 & -0.516 & -0.513 \\
H36 & -0.523 & -0.551 \\
Ca43 & $\cdots$. & 1.964 \\
\hline
\end{tabular}

bikaverin(1) and its receptor-analyte complexes with thirteen (13) studied bioavailable metal ions are shown in Figures 1, and S1 and S2 respectively (see Supplementary information). The natural charge distribution (Table 1) and electrostatic potential map of bikaverin (1) were calculated to identify its appropriate cation binding site. The charge distribution data in Table 1 and electrostatic potential map of bikaverin (1) indicate that the pocket for the electrophilic addition of cations is the carbonyl and the hydroxyl oxygen atoms Figure2 (see the ground state structure of bikaverin).

The calculated free energy change $(\Delta G)$ and the binding energy $(\Delta \mathrm{E})$ values of receptor analyte complexes are presented in Table 2. The data in Table 2 reveals that the binding of all the studied bioavailablecations to bikaverin is thermodynamically feasible and these ions bind the bikaverin receptor (1) with a range of strength. The trend in the binding propensity of studied metal ions can be correlated to their charge densities and hard soft acid base strength. It is evident from the binding and free energy data of Table 2 that the electrophillic binding of $\mathrm{Ca}^{2+}$, 
Table 2. Calculated free energy change $(\Delta \mathrm{G})$ and binding energy for receptor-analyte complexes using CAM-B3LYP/6-311Glevel of theory with basis set superposition error (BSSE) corrections.

\begin{tabular}{lccccccc}
\hline S. No & Adduct & $\begin{array}{c}\Delta \mathbf{G} \\
(\mathbf{K c a l} / \mathbf{m o l})\end{array}$ & $\begin{array}{c}\text { Binding energy } \\
(\mathbf{K c a l} / \mathbf{m o l})\end{array}$ & $\mathbf{S . ~ N o}$ & Adduct & $\begin{array}{c}\Delta \mathbf{G} \\
(\mathbf{K c a l} / \mathbf{m o l})\end{array}$ & $\begin{array}{c}\text { Binding energy } \\
(\mathbf{K c a l} / \mathbf{m o l})\end{array}$ \\
\hline 01 & $\mathbf{1}-\mathbf{N a}^{+}$ & -22.44 & -41.94 & 08 & $\mathbf{1}-\mathbf{M n}^{2+}$ & -43.76 & -31.81 \\
02 & $\mathbf{1}-\mathbf{K}^{+}$ & -19.92 & -39.31 & 09 & $\mathbf{1}-\mathbf{F e}^{2+}$ & -55.39 & -50.11 \\
03 & $\mathbf{1}-\mathbf{A l}^{3+}$ & -53.09 & -52.96 & 10 & $\mathbf{1}-\mathbf{N i}^{2+}$ & -27.11 & -29.72 \\
04 & $\mathbf{1}-\mathbf{P b}^{2+}$ & -51.31 & -22.72 & 11 & $\mathbf{1}-\mathbf{C u}^{2+}$ & -34.64 & -39.94 \\
05 & $\mathbf{1}-\mathbf{H g}^{2+}$ & -15.29 & -34.20 & 12 & $\mathbf{1}-\mathbf{M g}^{2+}$ & -51.97 & -58.63 \\
06 & $\mathbf{1}-\mathbf{C d}^{2+}$ & -22.64 & -45.29 & 13 & $\mathbf{1}-\mathbf{C a}^{2+}$ & -73.19 & -69.21 \\
07 & $\mathbf{1}-\mathbf{Z n}^{2+}$ & -31.66 & -23.77 & & & & \\
\hline
\end{tabular}

$\mathrm{Mg}^{2+}$ and $\mathrm{Al}^{3+}$ with receptor (1) is stronger in comparison to the remaining cations. Among all the studied metal ions the binding of $\mathrm{Ca}^{2+}$ to bikaverin was found to be strongest which suggests a possible interaction between bikaverin and $\mathrm{Ca}^{2+}$ at lower concentrations. Thus a sensing application of bikaverin towards $\mathrm{Ca}^{2+}$ ions at its physiological concentrations can be possible

Motivated by the binding of metal ions to bikaverin receptor(1), we attempted to explore the fluorescence behavior of the studied metal ions for predicted sensing applications. To get an insight into the origin of absorption and emission bands, the transitions of bikaverin(1) and its receptor-analyte complexes under consideration were simulated using preferred DFT/TD-DFT level of theory (Experimental section). The computationallypredicted spectra of studied metal ion bikaverin (1) adducts in the acetonitrile solvent depicted various peaks. However only the peaks of good intensity fluorescence were chosen for analysis. The major absorption and fluorescence intensity band of bikaverin (1) and its receptor-analyte adducts with studied metal ions are summarized in Table 3. The calculated absorption spectrumfor bikaverin (1) shows a major peak $(\lambda$ abs $)$ at $491 \mathrm{~nm}(2.52 \mathrm{eV})$. The metal ion bikaverin adducts showed varied emission responses in which the fluorescence intensities in some cases were seen to be attenuated and in some cases enhanced. The calculated fluorescence intensities of $1-\mathrm{Ca}^{2+}, 1-\mathrm{Mg}^{2+}$ and $1-\mathrm{Al}^{3+}$ adducts were found to be significantly higher than that of bikaverin (1) while as the absorption intensities of other receptor-analyte complexes don't show much deviation in comparison to pure bikaverin (1).

To have a further insight into the emission behavior of the bikaverin (1) metal ion adducts, the frontier molecular orbitals (FMOs) analysis was attempted. The FMOs of the bikaverin (1) and some representative receptor-analyte complexes are depicted in Fig. 3. The highest occupied molecular orbital (HOMO) and lowest unoccupied molecular orbitals (LUMO) energies of bikaverin (1) and all its metal ion adducts have been summarized in (Table S1, see supporting information). The interactions between the metal ions and the bikaverin (1) can be clearly observed from the frontier molecular orbital contour distribution. ${ }^{33}$
Table 3. Summary of absorption and fluorescence spectral data of bikaverin(1) and its analyte complexes

\begin{tabular}{ccccc}
\hline Molecule & $\begin{array}{c}\text { Calculated } \\
\boldsymbol{\lambda}_{\text {abs }}(\mathbf{n m})\end{array}$ & $\begin{array}{c}\text { Oscillator } \\
\text { strength } \\
(\boldsymbol{f})\end{array}$ & $\begin{array}{c}\text { Calculated } \\
\boldsymbol{\lambda}_{\text {flu }}(\mathbf{n m})\end{array}$ & $\begin{array}{c}\text { Oscillator } \\
\text { strength } \\
(\boldsymbol{f})\end{array}$ \\
\hline 1 & 491 & 0.2524 & 576 & 0.0102 \\
$1-\mathrm{Na}+$ & 412 & 0.1960 & 426 & 0.0081 \\
$1-\mathrm{K}+$ & 315 & 0.1910 & 370 & 0.0013 \\
$1-\mathrm{Ni2}+$ & 441 & 0.2103 & 494 & 0.0014 \\
$1-\mathrm{Al} 3+$ & 342 & 0.1543 & 388 & 0.1976 \\
$1-\mathrm{Hg} 2+$ & 377 & 0.1130 & 435 & 0.0045 \\
$1-\mathrm{Cd}+$ & 389 & 0.1866 & 437 & 0.0043 \\
$1-\mathrm{Mn} 2+$ & 422 & 0.2010 & 497 & 0.0036 \\
$1-\mathrm{Fe} 2+$ & 360 & 0.2349 & 454 & 0.0045 \\
$1-\mathrm{Zn} 2+$ & 390 & 0.1873 & 437 & 0.0033 \\
$1-\mathrm{Cu} 2+$ & 391 & 0.1033 & 463 & 0.0002 \\
$1-\mathrm{Mg} 2+$ & 372 & 0.1537 & 422 & 0.1278 \\
$1-\mathrm{Pb} 2+$ & 418 & 0.1004 & 471 & 0.0037 \\
$1-\mathrm{Ca} 2+$ & 525 & 0.1629 & 588 & 0.3722 \\
\hline
\end{tabular}

In case of bikaverin (1), the HOMO and LUMO are spread evenly over the benzoquinone and hydroquinone rings of the molecule. The observed changes in the HOMO and LUMO contours of bikaverin (1) indicate a pi to $\mathrm{pi}^{\star}$ transition in absorption. However, HOMOs and LUMOs in the receptor-analyte adducts are budged on different regions of the adducts indicating intramoleculor charge transfer due to the binding of cationic species.

It can also be seen from the Fig. 3 that the orbital contour distribution of HOMO in case of bikaverin calcium ion adduct $\left(1-\mathrm{Ca}^{2+}\right)$ gets shifted towards the opposite end compared to free bikaverin (1) or $1-\mathrm{Al}^{3+}$ and $1-\mathrm{Mg}^{2+}$ adducts. The calculated fluorescence wavelength for bikaverin (1) was found to be $576 \mathrm{~nm}(2.15 \mathrm{eV})$ with oscillator strength of 0.0102 , depicting low intensity fluorescence peak in bikaverin (1). While the calculated fluorescence spectrum of $1-\mathrm{Ca}^{2+}$ shows an intense peak at $588 \mathrm{~nm}(2.19$ $\mathrm{eV}$ ) with oscillator strength of 0.3722 .

Thus the observations of strong $\mathrm{Ca}^{2+}$ ion binding coupled with the enhancement in the fluorescence intensity of bikaverin (1) on $\mathrm{Ca}^{2+}$ ion binding predict the bikaverin 


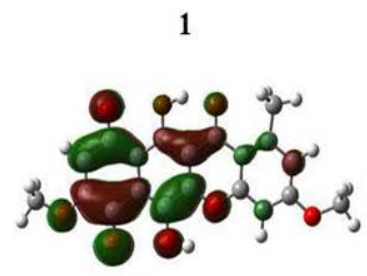

LUMO

$(1.021 \mathrm{eV})$

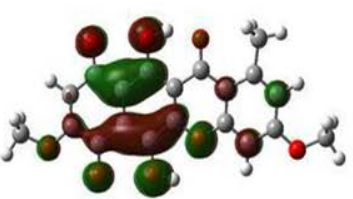

HOMO

$(-1.499 \mathrm{eV})$
$1-\mathrm{Al}^{3+}$

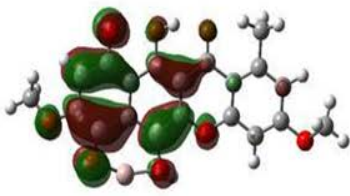

LUMO+2

(2.371)

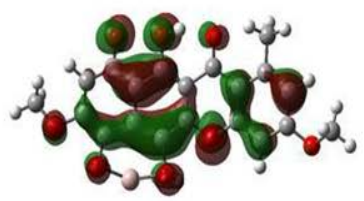

HOMO

$(-1.249 \mathrm{eV})$

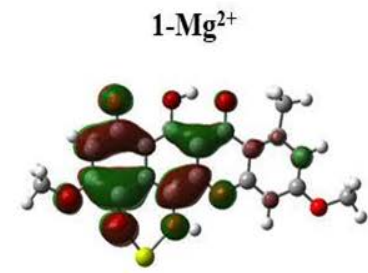

LUMO+3

$(2.109 \mathrm{eV})$

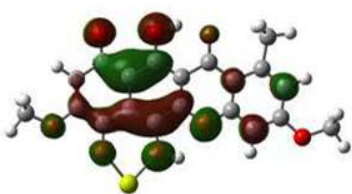

HOMO

$(-1.221 \mathrm{eV})$

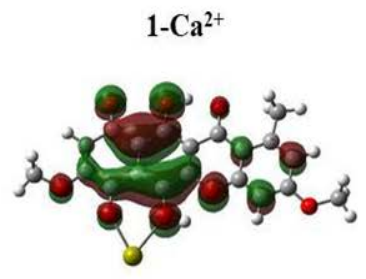

LUMO+1

$(1.227 \mathrm{eV})$

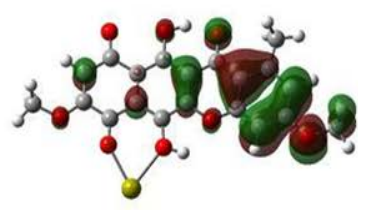

HOMO

$(-1.133 \mathrm{eV})$

Fig. 3. Frontier molecular orbitals of bikaverin (1), 1- $\mathrm{Al}^{3+}, 1-\mathrm{Mg}^{2+}$ and 1-Ca ${ }^{2+}$.

(1) as the new possible fluorescent biosensor for $\mathrm{Ca}^{2+}$ ion. The fluorescence imaging of $\mathrm{Ca}^{2+}$ ions in the form of bikaverin (1) calcium adduct can serve as a method for analyzing signaling pathways involving calcium ions. Besides, the changes in the intracellular $\mathrm{Ca}^{2+}$ ion concentrations have been related to different physiological, pathological and immune responses, therefore bikaverin based calcium ion sensing can also be an important tool in diagnostics.

The calculated oscillator strengths of fluorescence intensities of studied bioactive metal ions with bikaverin

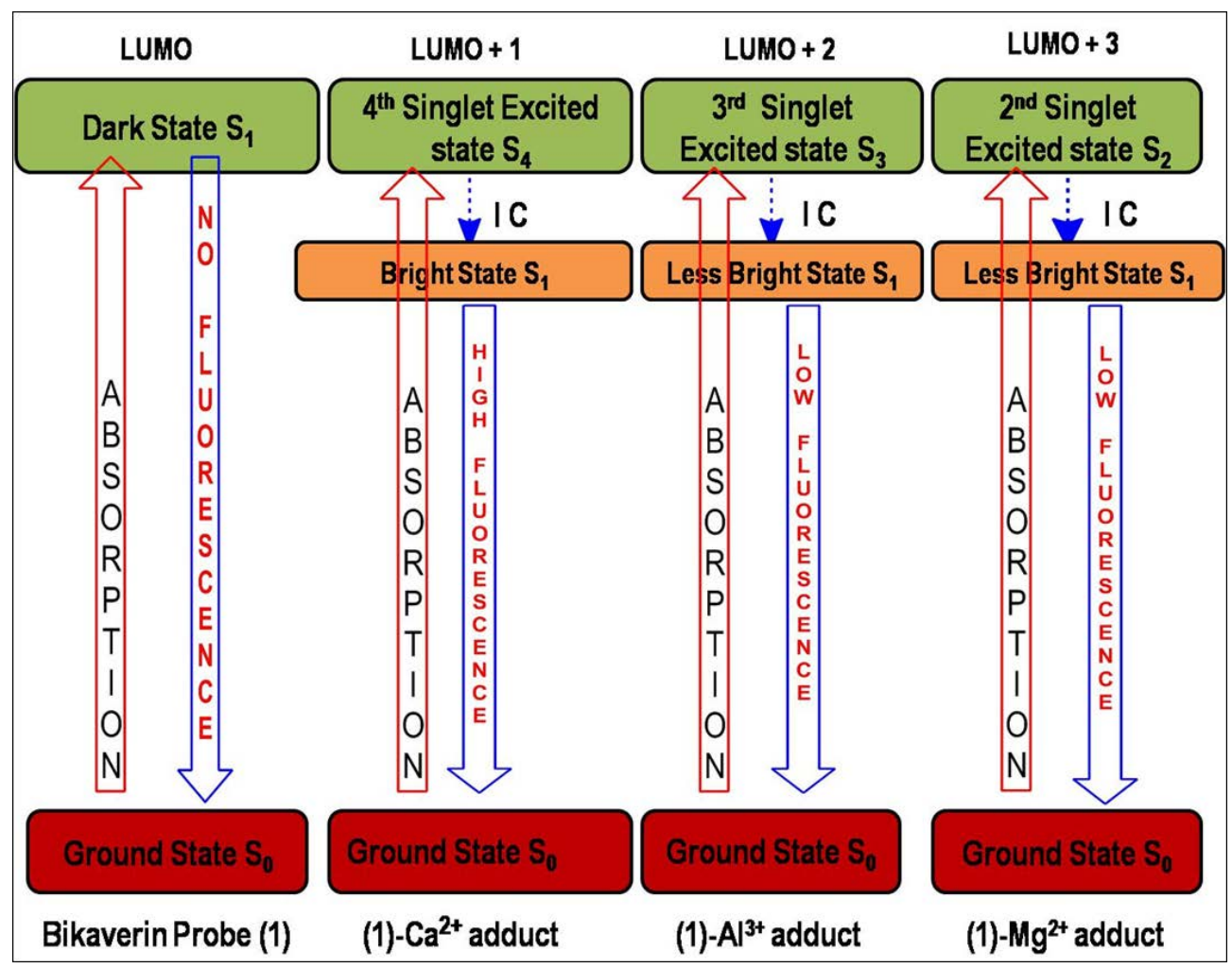

Fig. 4. Predicted electronic excitations and de excitations of bikaverin receptor (1) and its calcium adduct. 
(1) also predict a mild to medium increase in the intensity in case of $1-\mathrm{Mg}^{2+}$ and 1- $\mathrm{Al}^{3+}$ adducts. But the intensities of their fluorescence peaks are predicted to be smaller in comparison to $\mathrm{Ca}^{2+}$ as depicted by their oscillator strengths of 0.1976 and 0.1278 , respectively. For the other cationic species, there is no significant effect on the fluorescence intensities once they bind with the bikaverin receptor (1) as can be seen from their oscillator strengths in Table 3. It is therefore predicted from the DFT/TD-DFT calculations that receptor (1) can strongly sense $\mathrm{Ca}^{2+}$ ions fluorometrically with the milder sensing ability towards $\mathrm{Mg}^{2+}$ and $\mathrm{Al}^{3+}$ among the studied bioactive metal ions. The probable reason for the fluorescence intensity enhancement in case of $1-\mathrm{Ca}^{2+}, 1-\mathrm{Al}^{3+}$, and $1-\mathrm{Mg}^{2+}$ adducts is that their absorption transitions involve electron shifting to higher singlet excited states like fourth singlet excited state (S4),third singlet excited state(S3) and second singlet excited state(S2) in case of $1-\mathrm{Ca}^{2+}, 1-\mathrm{Al}^{3+}$, and $1-\mathrm{Mg}^{2+}$ respectively. As per $\mathrm{Ka}-$ sha's rule, ${ }^{34}$ the fluorescence phenomenon occurs from the firstsinglet excited state (S1). In order for fluorescence to occur, the higher excited states have to relax to the first singlet excited state. For this relaxation process, internal conversions and the vibrational relaxations occur which lead to the loss of energy during the de-excitation. Due to this energy loss there is significant Stoke's shift (change between absorption and emission energies) While as in the other cations and in receptor (1), the transitions involve the lowest singlet excited state S1. So there is no internal conversion and hence no energy loss and eventually no Stoke's shift. Hence, in such cases, there is either no fluorescence or the intensity of the fluorescence is very weak.

TD-DFT calculated results show that the main transitions for bikaverin(1), $1-\mathrm{Al}^{3+}, 1-\mathrm{Mg}^{2+}$ and $1-\mathrm{Ca}^{2+}$ are from $\mathrm{HOMO} \rightarrow \mathrm{LUMO}, \mathrm{HOMO} \rightarrow \mathrm{LUMO}+2, \mathrm{HOMO} \rightarrow$ $\mathrm{LUMO}+3$ and $\mathrm{HOMO} \rightarrow \mathrm{LUMO}+1$ respectively see Fig 4 . In all other receptor-analyte complexes, the main transitions involve $\mathrm{HOMO} \rightarrow$ LUMO.

The experimental and theoretical fluorescence study of bikaverin (1) reveala major fluorescence peak corresponding to HOMO to LUMO transition with $\lambda_{\mathrm{em}} 576 \mathrm{~nm}$ in the theoretical spectra and $\lambda_{\mathrm{em}} 425 \mathrm{~nm}$ in experimental spectra. However on binding of $\mathrm{Ca}^{2+}$ the theoretical fluorescence peak gets shifted to a value $\lambda_{\mathrm{em}} 588 \mathrm{~nm}$ which closely corroborateswith the observed experimentalpeak of Bikaverin $\mathrm{Ca}^{2+}$ adduct around $\lambda_{\mathrm{em}}$ of $620 \mathrm{~nm}$. Thus, the theoretically predicted red shift in fluorescence of bikaverin(1) on calcium ion binding was also experimentally observed and therefore can be rationalized with theoretical prediction of $\mathrm{HOMO} \rightarrow \mathrm{LUMO}+1$ absorption in case bikaverin calcium ion adduct.

\section{1. Characterization of Bikaverin from Fungal Extract}

The developments in synthetic biology has allowed tuning of microbial systems for generating industrially viable strains as the green and sustainable sources of value-added compounds. ${ }^{35}$ The composition and amounts of metabolites(bikaverin) are specific to the species of genus Fusarium. The morphological features of our crude fungal extract matched to the species Fusarium proliferatum. The chemical structure of purified bikaverin was confirmed through comparative analysis of NMR, mass, $\lambda \max$ and TLC of isolated compound with bikaverin standard and further to the literature reported values. ${ }^{36}$ ${ }^{1} \mathrm{H}-\mathrm{NMR}$ (CDCl3, 400MHZ): $\delta 2.87$ (3H, s, 1-Me), 3.93

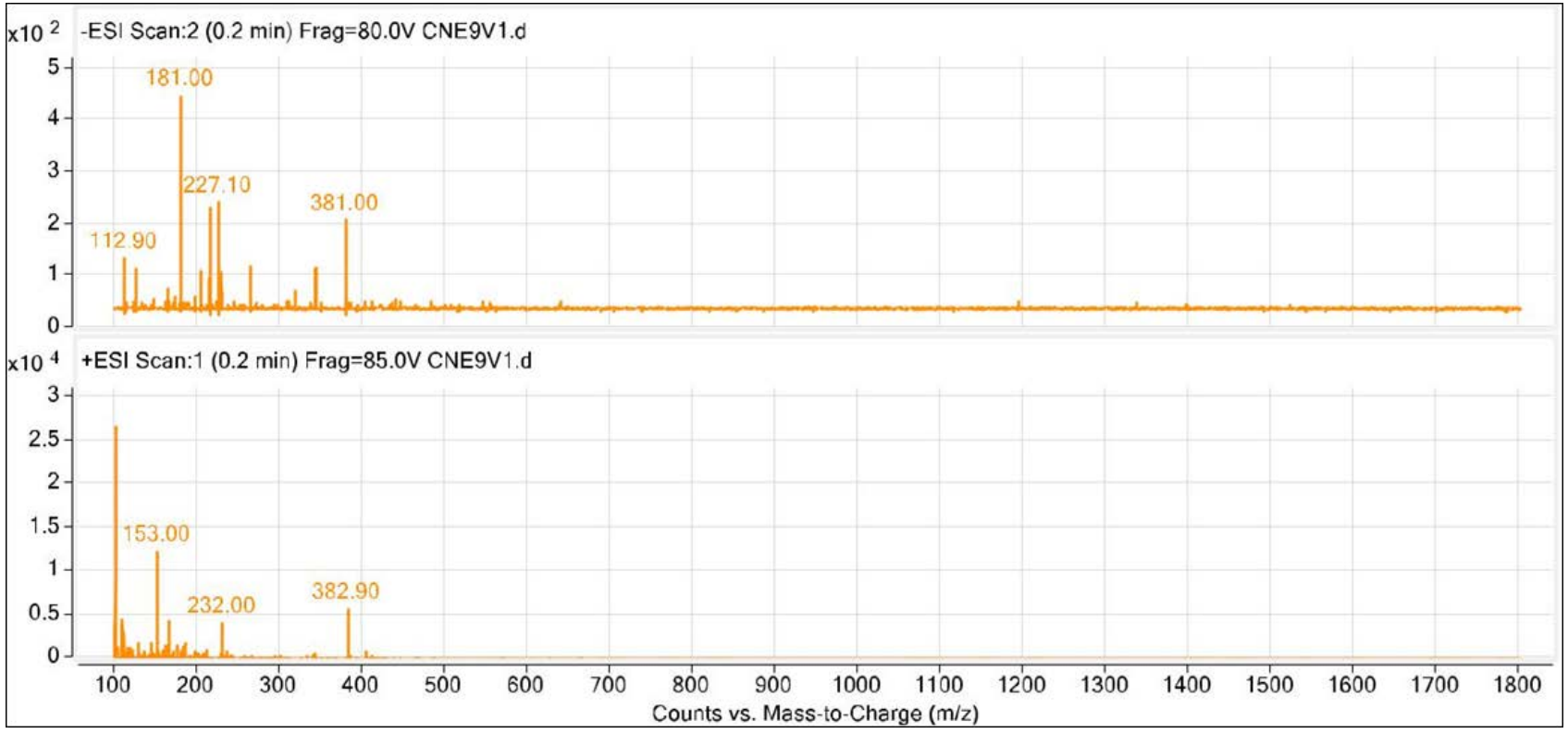

Fig. 5. Mass spectra of isolated product Bikaverin 
(3H, s, 8-OMe), 3.96 (3H, s, 3-OMe), 6.35 (1H, s, H-9), $6.81(1 \mathrm{H}, \mathrm{s}, \mathrm{H}-2), 6.93(1 \mathrm{H}, \mathrm{s}, \mathrm{H}-4)$.HRMS (ESI $\left.{ }^{+}\right)$calculated for $\mathrm{C} 20 \mathrm{H} 14 \mathrm{O} 8[\mathrm{M}+\mathrm{H}]^{+}$: 381.0761 , found: 382.90 Fig.5.

\section{2. Metal Ion Sensing Applications}

The preliminary metal ion sensing behavior of bikaverin (1) was studied towards selected bioactive metal ions as their chloride/perchlorate salts in $\mathrm{CH}_{3} \mathrm{CN} / \mathrm{H}_{2} \mathrm{O}$ (6:4, v/v; buffered with PBS, $\mathrm{pH}$ 7.4) using fluorescence spec- troscopy Fig 6. The fluorescence spectrum of receptor (1) $(10.0 \mu \mathrm{M})$ exhibits a weak emission band at $620 \mathrm{~nm}$ corresponding to bikaverin moiety when excited at $596 \mathrm{~nm}$ in $\mathrm{CH}_{3} \mathrm{CN} / \mathrm{H}_{2} \mathrm{O}(6: 4, \mathrm{v} / \mathrm{v}$; buffered with $\mathrm{PBS}, \mathrm{pH}=7.4)$. The weak fluorescence emission behavior of bikaverin is due to intramolecular charge transfer process as seen from HOMO- LUMO orbital contours.

It is evident from Figure 7 that on binding of calcium ions to bikaverin (1) its fluorescence profile gets modified. The free bikaverin shows very little to no fluorescence when excited at $596 \mathrm{~nm}$ while as the calcium bound bika-

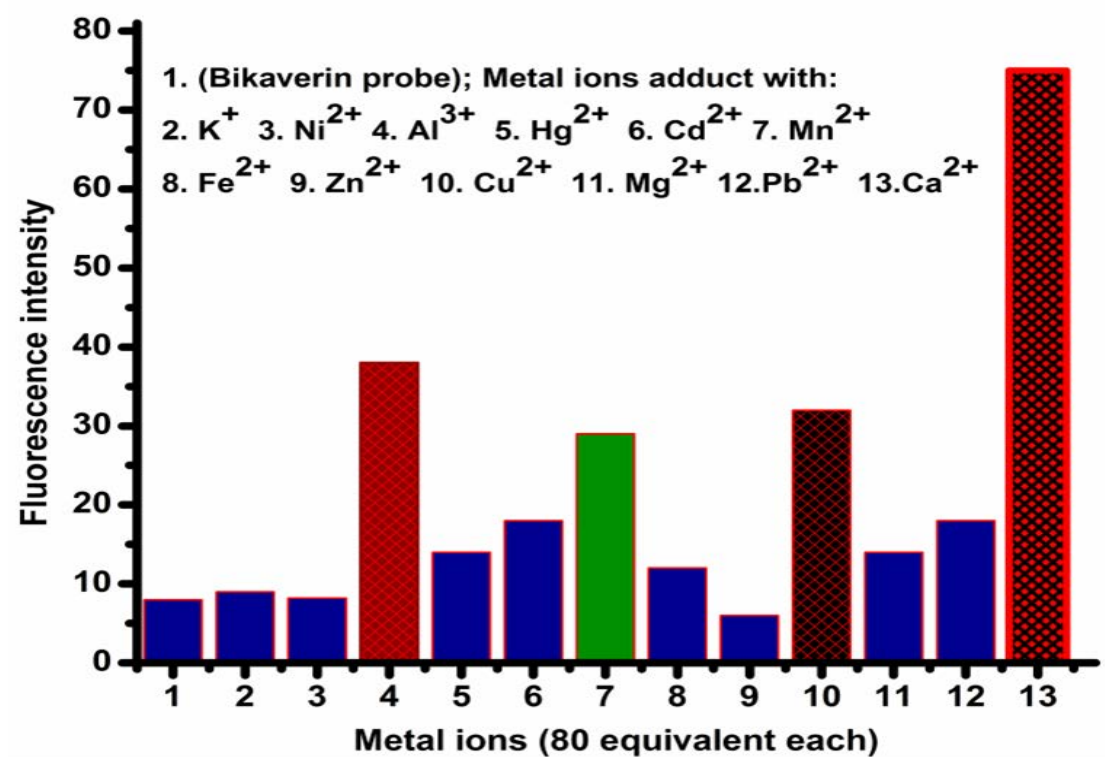

Fig. 6. Fluorescence response of bikaverin (1) towards various metal ions: Bars represent fluorescence selectivity (I/Io) of bikaverin (1) (10.0 $\mu \mathrm{M})$ towards various metal ions ( 80 equiv each) in $\mathrm{CH} 3 \mathrm{CN}: \mathrm{H} 2 \mathrm{O}(6: 4, \mathrm{v} / \mathrm{v})$ buffered with $0.05 \mathrm{M}$ HEPES, $\mathrm{pH}=7.4 ; \lambda$ ex $=596 \mathrm{~nm}$. The experimental fluorescence spectra of bikaverin(1) and its calcium adduct under different excitation wavelengths are shown in Fig.7 (A,B) respectively.

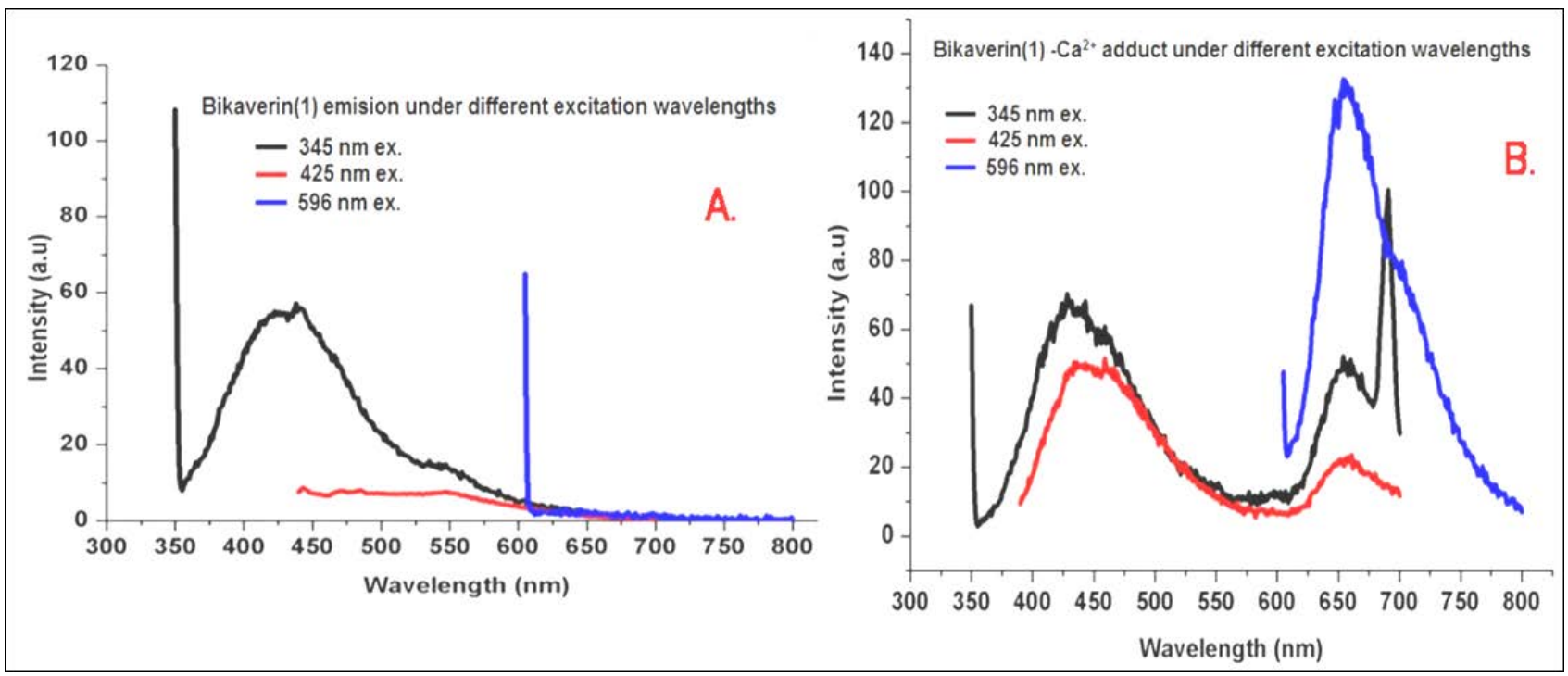

Fig. 7. Fluorescence response under different excitation wavelengths for A: bikaverin(1) B: Bikaverin $\mathrm{Ca}^{2+}$ adduct. 
verin shows a major fluorescence when excited at the 596 $\mathrm{nm}$ wavelength. Among the fluorescence peaks obtained under the excitation wavelengths of 425 and $345 \mathrm{~nm}$, the former gets an enhancement in the emission intensity while as the latter peak remains largely unchanged on calcium ion binding to bikaverin.

\section{Conclusions}

In summary, the present work describes a thorough computational investigation of metal ion sensing ability of natural pigment bikaverin as a fluorescent probe. An exploration of comparative metal ion binding affinities and optical properties of the bikaverin adducts through systematic studies using the appropriate level of theory are presented. The $\mathrm{Ca}^{2+}, \mathrm{Mg}^{2+}$ and $\mathrm{Al}^{3+}$ metal ions are shown to bind the bikaverin receptor more strongly and with an enhancement in its florescence intensity. The strongest binding affinity with the most intense fluorescence emission in case of $\mathrm{Ca}^{2+}$ predicts bikaverin pigment as a possible $\mathrm{Ca}^{2+}$ biosensor. The concept of isolation of bikaverin receptor (1) from the natural source as an economical and sustainable method is also presented. The computationally predicted metal ion fluorescence behavior of bikaverin receptor (1) towards the studied metal ions was experimentally corroborated through the preliminary fluorescence studies. Among the studied metal ions, the bikaverin receptor (1) was seen to strongly detect $\mathrm{Ca}^{2+}$ ions with an enhancement of fluorescence emission in its $\mu \mathrm{M}$ concentration range in the buffered aqueous medium due to charge transfer phenomena. The inclusive experimental studies of the bikaverin receptor (1) towards the selective calcium ion sensing under physiological conditions, the complete analytical profile of bikaverin as biosensor, the real time imaging of $\mathrm{Ca}^{2+}$ ions in cells through confocal microscopy and other related studies for the buildup of bikaverin as $\mathrm{Ca}^{2+}$ ion biosensor are underway in our laboratory.

\section{Acknowledgement}

MAR thankfully acknowledges Dr Hemant J Purohit, Chief Scientist \& Head Environmental Genomics Division, National Environmental Engineering Research Institute (NEERI), CSIR, Nagpur India for providing the Bikaverin crude extract for bikaverin extraction and University of Kashmir for assistance under UGC $12^{\text {th }}$ innovative research activity. HRB and MKR are highly thankful to Indian Institute of Technology Kanpur, India for providing some computational facilities.

\section{Conflict of Interest}

All the authors declare no conflict of interest what so ever.

\section{References}

1. H. Nikoofard, M. Sargolzaei, F. Faridbod Acta Chim. Slov. 2017, 64, 842-848. DOI:10.17344/acsi.2017.3357

2. S. Krishnamurty, M. Stefanov, T. Mineva, S. Bégu, J. M. Devoisselle, A. Goursot, R. Zhu, D. R. Salahub, J. Phys. Chem. B. 2008, 112, 13433-13442. DOI:10.1021/jp804934d

3. G. J. Cheng, X. Zhang, L. W. Chung, L. Xu, Y. D. Wu, J. Am. Chem. Soc. 2015, 137, 1706-1725. DOI:10.1021/ja5112749

4. F. Odame, Acta Chim. Slov. 2018, 65, 328-332 DOI:10.17344/acsi.2017.4001

5. A. T. Castro, J. D. Figuero-Villar, Int. J. Quantum Chem. 2002, 89, 135-146. DOI:10.1002/qua.10302

6. M. Lintuluoto, J. M. Lintuluoto, Biochemistry. 2016, 55, 46974707. DOI:10.1021/acs.biochem.6b00423

7. S. Arulmozhiraja, M. Morita, Chem. Res. Toxicol. 2004, 17, 348-356. DOI:10.1021/tx0300380

8. N. Yasarawan, K. Thipyapong, V. Ruangpornvisuti, J. Mol. Graphics Model. 2014, 51,13-26.

DOI:10.1016/j.jmgm.2014.04.009

9. F. Senn, M. Krykunov, J. Phys. Chem. A. 2015, 119, 1057510581. DOI:10.1021/acs.jpca.5b07075

10. M. H. Bridge, E. Williams, M. E. G. Lyons, K. F. Tipton, W. Linert. Biochim. Biophys. Acta. 2004, 1690, 77-84.

DOI:10.1016/j.bbadis.2004.05.007

11. Y. Wu, B. Midinov, R.J. White, ACS Sens., 2019, 4, 498-503. DOI:10.1021/acssensors.8b01573

12. M. A. Rizvi, M. Mane, M. A. Khuroo, G. M. Peerzada, Monatsh Chem. 2017, 148, 655-668.

DOI:10.1007/s00706-016-1813-8

13. Y. Dangat, M. A. Rizvi, P. Pandey, K. Vanka, J Organomet Chem. 2016, 801, 30-41.

DOI:10.1016/j.jorganchem.2015.10.015

14. M.V. Mane, M. A. Rizvi, K. Vanka, J. Org. Chem. 2015, 80, 2081-2091. DOI:10.1021/jo5023052

15. M. Kumar, A. Kumar, M. Rizvi, M. Mane, K. Vanka, S. C. Taneja, B. A. Shah, Eur. J. Org. Chem. 2014, 2014, 5247-5255. DOI:10.1002/ejoc.201402551

16. A. Pandey, M. Rizvi, B. A. Shah, S, Bani, Cytokine, 2016, 79, 103-113. DOI:10.1016/j.cyto.2016.01.004

17. A. Goswami, B. A. Shah, A. Kumar, M. A. Rizvi, S. Kumar, S. Bhushan, F. A. Malik, N. Batra, A. Joshi, J. Singh,Chem.-Biol. Interact., 2014, 222, 60-67. DOI:10.1016/j.cbi.2014.08.011

18. R Chib, M. Kumar, M. Rizvi, S. Sharma, A. Pandey, S. Bani, S. S Andotra, S. C. Taneja, B. A Shah, RSC Advances, 2014, 4, 8632-8637. DOI:10.1039/c3ra46412a

19. J. Balan, J. Fuska, I. Kuhr, V. Kuhrova, Folia Microbiol (Praha). 1970, 15, 479-484. DOI:10.1007/BF02880192

20. J. F. Henderson, M. L. Battell, G. Zombor, J. Fuska, P. Nemec, Biochem Pharmacol. 1977 26, 1973-1977.

DOI:10.1016/0006-2952(77)90004-1

21. D. Kjaer, A. Kjaer, C. Pedersen, J. D. Bulock, J. R. Smith, J Chem Soc Perkin 1. 1971, 16, 2792-2797. DOI:10.1039/J39710002792

22. M. C. Limon, R. Rodríguez, J. Avalos, Appl Microbiol Biotechnol. 2010, 87, 21-29. DOI:10.1007/s00253-010-2551-1

Hussain et al.: Exploring Bikaverin as Metal ion Biosensor: ... 
23. D. Arora, N. Sharma, V. Singamaneni, V. Sharma, M. Kushwaha, V. Abrol, S. Guru, S. Sharma, A. P. Gupta, S. Bhushan, S. Jaglan, P. Gupta, Phytomedicine. 2016, 23, 1312-1320.

DOI:10.1016/j.phymed.2016.07.004

24. Frisch, M. J.; Trucks, G. W.; Schlegel, H. B.; Scuseria, G. E.; Robb, M. A.; Cheeseman, J. R.; Scalmani, G.; Barone, V.; Mennucci, B.; Petersson, G. A.; et al. Gaussian 09; Gaussian Inc: Wallingford, CT, 2009.

25. T. Yanai, D. P. Tew, N. C. Handy, Chemical Physics Letters, 2004, 393, 51-57. DOI:10.1016/j.cplett.2004.06.011

26. Jacquemin, D.; Planchat, A.; Adamo, C.; Mennucci, B. J. Chem. Theory Comput. 2012, 8, 2359-2372.

DOI:10.1021/ct300326f

27. H. R. Bhat, P. C. Jha, Chem. Phys. Lett. 2017, 669, 9-16. DOI:10.1016/j.cplett.2016.12.025

28. H. R. Bhat, P. C. Jha, Phys. Chem. Chem. Phys. 2017, 19, 14811-14820. DOI:10.1039/C7CP02287E

29. H. R. Bhat, P. C. Jha, J. Phys. Chem. A. 2017, 121, 3757-3767. DOI:10.1021/acs.jpca.7b00502
30. S. F. Boys, F. Bernardi, Mol. Phys.1970, 19, 553-566. DOI:10.1080/00268977000101561

31. Reed, A. E.; Curtiss, L.; Weinhold, F. Chem. Rev. 1988, 88, 899-926. DOI:10.1021/cr00088a005

32. J. W. Cornforth, G. Ryback, P. M. Robinson, D. Park, J Chem Soc Perkin 1971, 1.16, 2786-2788.

DOI:10.1039/j39710002786

33. R. M. Jagtap, M. A. Rizvi, Y. B. Dangat, Satish K. Pardeshi, J. Sulfur Chem. 2016, 37, 401-425.

DOI:10.1080/17415993.2016.1156116

34. M. Kasha, Discuss. Faraday Soc. 1950, 9, 14-19. DOI:10.1039/df9500900014

35. J. Du, Z. Shao, H. Zhao, J Ind Microbiol Biotechnol. 2011, 38, 873-890. DOI:10.1007/s10295-011-0970-3

36. D. Kjaer, A. Kjaer, C. Pedersen, J. D. BuLock, J. R. Smith, J. Chem. Soc. C 1971, 0, 2792-ww2797.

DOI:10.1039/J39710002792

\section{Povzetek}

Članek predstavlja računalniško raziskovanje gliv, ki proizvajajo pigment bikaverin kot biosensor za biološko razpoložljive kovinske ione. Narejene so bile sistematične študije geometrije optimiziranega osnovnega in vzbujenega stanja za raziskovanje vezavnega žepa za kovinske ione, primerjalna vezavna nagnjenost in optične lastnosti bikaverina in njegovih aduktov s preiskovanimi kovinskimi ioni. Pregled trinajstih (13) biodostopnih kovinskih ionov je pokazal, da jakost vezanja na bikaverinski receptor ustreza zaporedju $\mathrm{Ca}^{2+}, \mathrm{Mg}^{2+}$ in $\mathrm{Al}^{3+}$. Po vezavi na bikaverinski receptor je bila opažena ojačitev fluorescence v vrstnem redu $\mathrm{Ca}^{2+}>\mathrm{Al}^{3+}>\mathrm{Mg}^{2+}$. Računsko napovedana selektivnost bikaverinskega receptorja $\mathrm{za} \mathrm{Ca}^{2+}$ je bila eksperimentalno podprta s predhodnimi fluorescenčnimi študijami. Bikaverinska sonda je pokazala povečanje fluorescenčne emisije v prisotnosti $\mathrm{Ca}^{2+}$ ionov v zapufranem vodnem mediju. 